French, R. C. 1953. The effect of growth regulators and allied compounds on growth and respiration of maize tissues. Thesis. Purdue Univ. Lafayette, Indiana.

Lardy, H. A., and H. Wellman. 1952. Oxidative phos. phorylations: Role of inorganic phosphate and acceptor systems in control of metabolic rates. Jour. Biol. Chem. 195: 215-224.

$\longrightarrow$ - and C. Feldott. 1952. Mechanism of action of dinitrophenol and thyroxine. Abstracts, Spring Meeting, Div. Biol. Chem., Amer. Chem. Soc.

Mitchell, J. E., R. H. Burris, ANd A. J. Riker. 1949. Inhibition of respiration in plant tissues by callus stimulating substances and related chemicals. Amer. Jour. Bot. 36: 368-378.

Nance, J. F., and L. W. Cunningham. 1950. Acetaldehyde accumulation in excised wheat roots induced by plant growth substances. Science 112: 170-172.

Rhodes, A., And R. DE B. Ashworth. 1952. Mode of action of growth regulators in plants. Nature 169: 76-77.

YAMAKI, T. 1949. Einfluss der Wuchstoffe auf den Atmungsvorgang der Koleoptile von Avena sativa. II. Mitteilung über Pflanzliche Wirkstoffe. Acta Phytochim. 15: 151-167.

\title{
STATUS OF AN ASIATIC MEMBER OF THE JUGLANDACEAE REGARDED AS A 'LIVING FOSSIL' '
}

\author{
Richard A. Scott ${ }^{2}$
}

THE DEsCRIPTION of a living representative of a genus known previously only from the fossil record is a rare event of considerable interest to both neoand paleobotanists. The extent of this interest may be measured in part by the large number of papers concerned with Metasequoia glyptostroboides since the discovery of this 'living fossil' was reported in 1948. Recently Dr. Hsen-Hsu Hu (1952), who had a part in the discovery of the modern Metasequoia, has concluded that a member of the walnut family now found in China and Indo-China is a living species of Juglandicarya, a genus previously known only from fossil fruits occurring in the Eocene London Clay formation of England. The writer, who recently examined the material of Juglandicarya in the collections of the British Museum (Natural History), believes that this assignment is in error. The following discussion reviews the available information on the living and fossil species as a basis for the contention that the species are not congeneric.

Unlike Metasequoia glyptostroboides, this Recent species has been known to botanists for a number of years. However, a lack of reference to the pertinent literature, in part unavoidable, by authors dealing with this species has led to much confusion with regard to its systematic position and nomenclature.

Fruits of the species were described as Carya sinensis by Dode (1912), but his description was overlooked until 1950. Meanwhile the species was again described from other material by Chevalier (1941), who placed it in a new genus, Annamocarya. Although naming this plant $A$. indochinen-

1 Received for publication April 25, 1953.

The author wishes to thank Mr. W. N. Edwards of the British Museum (Natural History) for his courtesy in permitting study of the material of Juglandicarya in the $\mathrm{Mu}$ seum's collections. This paper was written while the author was a Rackham postdoctoral fellow at the University of Michigan.

2 Present address: The Biological Laboratories, Harvard University. sis, Chevalier also inexplicably referred to it as Juglans indochinensis in the same paper. Later in the same year Kuang (1941) independently proposed another new genus, Rhamphocarya, whose single species, $R$. integrifoliolata, is also based upon material of the plant under discussion.

Hjelmqvist (1948), overlooking the earlier descriptions by both Dode and Chevalier, transferred the species from Rhamphocarya to Carya, creating the new combination $C$. integrifoliolata (Kuang) Hjelmqvist. W. Y. Chun had previously referred the species to Carya as C. tsiangii, but this combination was never published (Manning and Hjelm. qvist, 1951).

Leroy (1950) concluded that the species constitutes a distinct genus and, with full knowledge of the pertinent literature, proposed the new combination Annamocarya sinensis (Dode) Leroy as its name. Leroy's reason for taking the species out of Carya. was based chiefly upon the vascular structure of the fruit $(195 \mathrm{la}, \mathrm{b})$. He reported that the vascular strands extend from the base to the apex within the inner wall of the fruit rather than within the primary partition as is the case for both Carya and Juglans.

Manning and Hjelmqvist (1951), after examining all available herbarium material but without knowledge of Leroy's work, reaffirmed Hjelmqvist's earlier opinion that this Asiatic species belongs in Carya. As Leroy had done earlier, they linked Dode's description of Carya sinensis to the material at hand. After rejecting the possibility that the species is closely related to Juglandicarya, they concluded that its name should remain as Carya sinensis.

The first intimation that this Recent species might be a 'living fossil' was made by Chevalier when he described it as Annamocarya indochinensis. He considered that its fruits showed features suggesting both Juglans and Carya, and that the species might represent a form ancestral to these two genera. Merrill (1948), using the name Rhampho- 
carya, regarded the plant as a living representative of the fossil genus Caryojuglans Kirchheimer. The monotypic Caryojuglans, described from fruits found in European brown-coal beds, is regarded by Kirchheimer (1938) as an intermediate between Juglans and Carya.. Mädler (1939) believes that its single species should be assigned to Juglans, and Leroy (1952) assigns the species to Carya. The fruits of Juglans and Carya have several features in common and, particularly in the fossil state, are sometimes difficult to distinguish. Their characteristics have been discussed by Mädler and by Kirchheimer (1951). Both Kirchheimer (1951) and Manning and Hjelmqvist (1951), after examining fruits of the Recent 'Rhamphocarya', have rejected the possibility that it is a species of Caryojuglans. Kirchheimer has also expressed the opinion that the Asiatic species does not belong to Juglandicarya.

Hu's (1952) transfer of the problematic species to the fossil genus Juglandicarya is the most recently published opinion regarding its affinities. Of the papers cited above, Hu referred only to Kuang's work. It should be noted, however, that because of the length of the period during which Hu's paper was in press, he could not have seen any of the papers published during 1951. Hu considered the earliest previous name for the species to be Rhamphocarya integrifoliolata and created the new combination Juglandicarya integrifoliolata (Kuang) $\mathrm{Hu}$ to designate it.

The net result of this involved sequence is that since it was first described this one juglandaceous species has been associated with six generic names: Carya, Juglans, Annamocarya, Rhamphocarya, Caryojuglans, and Juglandicarya. There are currently three independent proposals regarding its designation in the literature: Annamocarya sinensis (Dode) Leroy, Carya sinensis Dode, and the one to be discussed here, Juglandicarya integrifoliolata (Kuang) $\mathrm{Hu}$.

The genus Juglandicarya was founded by Reid and Chandler (1933, p. 140) to contain "Fruits which, although clearly referable to the Juglandaceae, are of doubtful generic relationship both to living genera and to one another." It includes four published species, one of which, J. crassa (Bowerbank) Reid and Chandler, was based on material which had disintegrated in storage before the latter authors transferred it to Juglandicarya. The original description is not adequate for comparisons. Opinions regarding the possible affinities of the other three species are shown in table 1. These diverse opinions bear out the conclusion of Reid and Chandler that the species assigned to Juglandicarya do not constitute a single natural genus. It is often necessary for paleobotanists to erect genera of this sort; unfortunately, botanists who work chiefly with modern plants do not always recognize the element of artificiality inherent in them.

As would be expected where relationships can be established clearly only to family level, the observ-
TABLE 1. Summary of opinions regarding the possible affinities of the species of Juglandicarya Reid and Chandler.

\begin{tabular}{|c|c|c|c|}
\hline $\begin{array}{c}\text { Juglandicarya } \\
\text { Species }\end{array}$ & $\begin{array}{l}\quad \text { Nea } \\
\text { Reid and } \\
\text { Chandler } \\
(1933)\end{array}$ & $\begin{array}{l}\text { est Modern R } \\
\text { Kirchheimer } \\
\text { (1951) }\end{array}$ & $\begin{array}{l}\text { Relative } \\
\text { Manning and } \\
\text { Hjelmqvist } \\
\text { (1951) }\end{array}$ \\
\hline $\begin{array}{l}\text { J. lubbocki } \\
\text { J. cantia }\end{array}$ & $\begin{array}{l}\text { Juglans } \\
\text { Juglans }\end{array}$ & Engelhardtia & $\begin{array}{l}\text { Pterocarya, } \\
\text { Engelhardtia, }\end{array}$ \\
\hline$J$. depressa & $\begin{array}{l}\text { Pterocarya, } \\
\text { Juglans }\end{array}$ & Pterocarya & $\begin{array}{l}\text { Juglans } \\
\text { rupestris }\end{array}$ \\
\hline J. crassa & \multicolumn{3}{|c|}{ Specimens disintegrated in storage } \\
\hline
\end{tabular}

able features of the species of Juglandicarya are for the most part general ones typical for the walnut family and not necessarily limited to any one modern genus. Reid and Chandler's diagnosis of $J$. cantia is representative $(1933$, p. 142$)$ :

"Endocarp globular, smooth, and without external nodulations, dehiscing into equal valves, oneloculed, one-seeded; walls thick, without cavities. Seed erect, orthotropous, conforming to the shape of the locule, simple above, two-lobed below, each lobe being slightly emarginate at the base. Diameter of endocarp about $12 \mathrm{~mm}$."

The similarities upon which $\mathrm{Hu}$ bases the supposed congeneric relationship between 'Rhamphocarya and Juglandicarya are stated in this quotation (1952, p. 264) :

'Rhamphocarya has a smooth, globular to ellipsoid, one-loculed and one-seeded endocarp with thick wall without cavities. Its seed is erect, orthotropous, conforming to the shape of the locule, simple or emarginate above, deeply two-lobed below, the lobes again being shallowly two-lobed by a secondary septum. Its contours are smooth. These characteristics are similar to those of Juglandicarya; only the size of the endocarp is much larger."

This description of the fruit of 'Rhamphocarya' is obviously similar to the diagnosis of Juglandicarya cantia and is also like that of $J$. lubbocki. Of the species of Juglandicarya, $\mathrm{Hu}$ found these two to agree most closely with the modern species. The correspondence which he points out is not, however, adequate evidence for congeneric relationship. Hu's characterization of 'Rhamphocarya' is a generalized one which is also applicable in most respects to fruits of other genera in the walnut family, for example, Juglans and Carya. The only feature in which the agreement might indicate close relationship to Juglandicarya is the stated lack of cavities in the wall of the modern nut. Wall cavities, absent in Juglandicarya, are usually lacking in Carya but do occur in at least three species; they are always present in Juglans although sometimes greatly reduced. This similarity between 'Rham. phocarya' and Juglandicarya is not a reliable one, however, for Manning and Hjelmqvist (1951) have 
described and illustrated cavities in the wall of the nut near the apex in the modern species.

Except to note the much larger size of the fruit of the Asiatic species, $\mathrm{Hu}$ did not consider the differences between it and the species of Juglandicarya. Internal ridges, typical for Carya, are present on the nutshell of the modern form but are absent from Juglandicarya. As Manning and Hjelmqvist have pointed out, the seed of the modern species is compressed in the plane parallel to the primary partition rather than at right angles to this plane as are the seeds of J. cantia and J. lubbocki. The primary embryo lobes of $J$. cantia are entire at the base; J. lubbocki has a secondary partition which is as wide as the primary partition. The modern nut is prominently apiculate, but the nuts of these two Juglandicarya species are rounded.

The resemblances of the Asiatic species under consideration to the two species of Juglandicarya are only general ones, and there are significant differences between them. Through the courtesy of Miss M. E. J. Chandler and Mr. W. N. Edwards, Keeper of Geology, British Museum (Natural History), the writer was permitted to consult the manuscript of Miss Chandler's forthcoming publication in which additional species of Juglandicarya are described. None of these new species appears to be any more closely related to 'Rhamphocarya' than are $J$. cantia and $J$. lubbocki. No substantial evidence for the relationship of 'Rhamphocarya' to the fossil genus has been presented by $\mathrm{Hu}$, and his transfer -of the modern form to Juglandicarya is unjustified.

In addition to the question of affinity there are other objections to the use of the name Juglandicarya integrifoliolata (Kuang) $\mathrm{Hu}$ for the species under discussion. It has been established that this species was first described by Dode as Carya sinensis; hence Hu's combination is illegitimate. Article 68 of the new International Code of Botanical Nomenclature, which came into effect after $\mathrm{Hu}$ submitted his manuscript for publication, provides that when a taxon of Recent plants, except algae, and a taxon of the same rank of fossil or subfossil plants are united, the correct name of the former taxon must be accepted even if it is antedated by the latter. Thus use of the name Juglandicarya, based on fossil material, is now illegitimate for modern plants. If the relationship pointed out by $\mathrm{Hu}$ were correct, it would be necessary to transfer the related species of Juglandicarya to the genus to which the modern Asiatic species belongs. The underlying wisdom of this Article is well illus. trated in this case, for the transfer of a living species to Juglandicarya would place the species in a taxon whose members are of uncertain generic relationship to one another.

If this modern species is not related to Juglandicarya, what are its affinities? Two opinions remain: Manning and Hjelmqvist consider it to be a species of Carya, while Leroy believes that it constitutes a separate genus. Further investigation is needed before this question can be settled finally. Both the anatomy of the secondary xylem (Heimsch and Wetmore, 1939) and the morphology of the pollen (Heimsch, 1944) are useful in delimiting the genera in the Juglandaceae and for the most part sup. port the relationships suggested by Manning (1938) on the basis of his study of the floral morphology of the family. Thus it appears that when suffcient material becomes available to permit application of the varied approaches of modern taxonomy to this enigmatic Asiatic species, it may become possible to establish its correct affinities. Meanwhile, it seems advisable to refer to the plant as Carya sinensis, in the genus to which it was orig. inally assigned and which Manning and Hjelmqvist (1951) have lately reaffirmed as correct. One thing seems certain, however; the species is not a 'living fossil' in the sense of being a closely related survivor of those members of the walnut family that formed a part of the Paleotropical assemblage known to have flourished during the Eocene in the region of present-day England.

\section{SUMMARY}

Dr. Hsen-Hsu $\mathrm{Hu}$ has concluded that a member of the walnut family now found in China and Indo. China is a living species of Juglandicarya, a genus based on fossil fruits from the Eocene London Clay formation of England. The genus Juglandicarya was founded to include fossil juglandaceous fruits identifiable to family only, and its species are of doubtful relationship to one another. The features which $\mathrm{Hu}$ found to be cornmon to the living species and Juglandicarya are for the most part general ones also shared by other genera in the family. He ignored-important differences that exist between the modern and the fossil fruits. In the opinion of the present writer, these differences are sufficient to preclude their generic identity. There are also no. menclatorial objections to the use of the name proposed by Hu. This modern Asiatic species cannot be considered to be a 'living fossil' in the sense of being a closely related survivor of any of the extinct species included in the genus Juglandicarya.

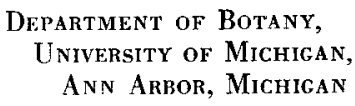

Department of Botany,

University of Michigan,

Ann Arbor, Michigan

\section{LITERATURE CITED}

Curevalier, A. 1941. Variabilité et hybridité chez les noyers. Notes sur des Juglans peu connus, sur l'Annamo. carya et un Carya d'Indochine. Rev. Inter. Bot. AppI. 21: $477-509$.

Dode, L. A. 1912. Deux genres nouveaux pour la Chine. Bull. Soc. Dendrol. France. 24: 58-61.

Hrimsch, C., Jr. 1944. Alfaroa pollen and generic relationships in the Juglandaceae. (Abstract) Amer. Jour. Bot. 31: 3s.

-, AND R. H. Wetmore. 1939. The significance of 
wood anatomy in the taxonomy of the Juglandaceae. Amer. Jour. Bot. 26: 651-660.

H.JelmQvist, H. 1948. Studies on the floral morphology and phylogeny of the Amentiferae. Bot. Notiser. Suppl. 2: 1-171.

Hu, H. H. 1952. On a living species of Juglandicarya found in south Yunnan. The Palaeobot. 1: 263-265.

Kirch heimer, F. 1938. Ein Beitrag zur Kenntnis der Alttertiärflora des Harzvorlandes. Planta 27: 615-644.

_. 1951. Über Antweileria und andere Gattungen der Juglandaceen. Planta 39: 527-541.

KuANG, K. Z. 1941. Genus novum Juglandacearum ex austro-orientali Yunnan. Icon. Flor. Sinicae 1: 1-3.

Leroy, J. F. 1950. Note sur les noyers (Carya et Annamocarya) sauvages d'Indochine. Rev. Inter. Bot. Appl. 333-334: 425-428.

- 1951a. Morphologie végétale. - Contre la théorie généralisée des carpelles-sporophylles. I. Une structure singularière d'axe invaginé et de placentation caulinaire chez Annomocarya A. Chev. (Juglandaceae). Compt. Rend. Acad. Sci. Paris. 232: 432-434. 1951b. Morphologie végétale.-Contre la théorie généralisée des carpelles-sporophylles. II. Phylogénie structurale de la placentation dans le groupe JuglansCarya (Juglandaceae). Compt. Rend. Acad. Sci. Paris 232: 1007-1009.

- 1952. Débat sur Annamocarya. Documents sur les Carya de l'ère tertiare. Rev. Inter. Bot. Appl. 355-356: 289-290.

Madler, K. 1939. Die pliozäne Flora von Frankfurt am Main. Abhandl. Senckb. Naturf. Ges. Frankfurt 446: $1-202$.

Manninc, W. E. 1938. The morphology of the flowers of the Juglandaceae. I. The inflorescence. Amer. Jour. Bot. 25: 407-419.

-, and H. Huelomqvist. 1951. Annamocarya, Rham. phocarya, and Carya sinensis. Bot. Notiser 4: 319-330.

MerriLl, E. D. 1948. A living Metasequoia in China. Science 107: 140 .

Reid, Eleanor M. and Marjorie E. J. Chandler. 1933. The London Clay flora. British Museum (Natural History). London.

\section{BIOSYSTEMATIC STUDIES IN ASTER. I. CROSSING RELATIONSHIPS IN THE HETEROPHYLLI ${ }^{1}$}

\section{Charlotte J. Avers}

THE COMPLEXITY of species pattern in the genus .ister has long been noted. Much of the taxonomic difficulty has been ascribed to the blurring of species boundaries by hybridization. The only previous experimental hybridization studies of asters were conducted by Wetmore and Delisle (1939) with Aster novae-angliae and $A$. ericoides (multiflorus). Several floristic studies of asters have been made recently (Shinners, 1941, 1945; Rosendahl and Cronquist, 1949) but the group under consideration here has never been subjected to cytogenetic analysis.

The present study concerns a group of nine closely-related aster species generally known as the HETEROPHYLLI. It is the purpose of this study to examine the concept of hybridization as a prominent cause for the taxonomic difficulty of the group and to examine those factors which may be operative in directing the evolutionary pattern of these species. The present paper is designed primarily to present a preliminary survey of the cross. ing relationships among seven of the heterophyllous species. The evolutionary consequences of the speciation pattern will be discussed elsewhere (Avers, 1953).

3 Received for publication April 30, 1953.

Part of a thesis submitted to the Graduate School of Indiana University in 1953 in partial fulfillment of the requirements for the degree of Doctor of Philosophy. The writer wishes to express her appreciation to Dr. Charles B. Heiser for his advice and criticisms throughout the course of this investigation. A portion of this work was carried out with the aid of the Kathryn McHale Fellowship granted by the American Association of University Women.

Present address: Botany Department, Connecticut College, New London, Connecticut.
The species under consideration here are morphologically similar in many respects. Varieties have been largely ignored in the present treatment. Many of the varieties now recognized are merely the result of hybridization and local ecological variation and their taxonomic recognition would burden the literature without elucidating the genetic relationships among the species.

The heterophyllous asters are perennial herbs which are most frequently found in small populations in shaded woodlands. The species occur in eastern North America except for the boreal $A$. ciliolatus Lindl. which extends from coast to coast. While several of these taxa are allopatric, many are sympatric over a large part of their range.

Cytology.-Determinations of chromosome numbers from pollen mother cells were made using the acetocarmine squash technique after preliminary fixation in chloroform-ethanol-acetic acid. $4: 3: 1$. The basic chromosome number in this group is 9, with diploid, tetraploid, and octaploid species represented. No multivalents were apparent in examinations of wild material of the parent species. Table I shows the chromosome numbers of the HETEROPHYLLI, which are here reported for the first time.

Meiotic behavior in the hybrids was examined and all $F_{1}$ hybrids evinced regularity of chromosome pairing although a small percentage of pollen mother cells contained two to four unpaired chromosomes. Hybrids between homoploid species showed no evidence of multivalent associations.

Pollen fertility was determined by relative stain- 